\title{
Intrapreneurship, Innovation, and Competitiveness in Organization
}

\author{
Greiciele Macedo Morais ${ }^{1}$, Valdeci Ferreira dos $\operatorname{Santos}^{1}$, Renata de Sousa da Silva Tolentino ${ }^{1} \&$ Henrique Cordeiro \\ Martins ${ }^{1}$ \\ ${ }^{1}$ Department of Business Administration, FUMEC University, Minas Gerais, Brazil \\ Correspondence: Valdeci Ferreira dos Santos, PhD student, Business Administration, FUMEC University, Minas \\ Gerais, Brazil.
}

Received: October 12, 2020

Accepted: December 17, 2020

Online Published: February 3, 2021

doi:10.5430/ijba.v12n2p1

URL: https://doi.org/10.5430/ijba.v12n2p1

\begin{abstract}
To ensure survival, seize opportunities, and resist threats in the unpredictable business scenario, companies increasingly adopt practices that enable intra-entrepreneur behavior. This behavior is characterized by the alignment of company members in search of innovative solutions for the development of the organization and building a competitive advantage. The current study reflects on the importance of intra-entrepreneurship and innovation for the competitiveness of the organization. This article discusses the development of intra-entrepreneurship, its characteristics, the factors that precede it, and also reflects on the relationship between intra-entrepreneurship, innovation, and competitiveness of organizations. The methodological approach consisted of a systematic descriptive-discursive review of the academic literature with research in databases (CAPES Journal Portal, EBSCO HOST, and Web of Science). The keywords used were: corporate entrepreneurship, intra-entrepreneurship, innovation, competitiveness, and competitive advantage (in Portuguese and English). The research found that intra-entrepreneurship and innovation go hand in hand. Together, they constitute dynamic and holistic processes in which employee behavior, combined with favorable organizational factors, affect the development of organizations and the possibility of developing a competitive advantage, not limited to new companies. This article contributes to the literature on intra-entrepreneurship, reinforcing its importance, along with innovation for organizational development. As a practical implication, the current work demonstrated the need to increase attention and appreciation of human capital as a strategic factor for achieving competitive advantage in organizations. For future research, we suggest seeking quantitative research that confirms the relationship between intra-entrepreneurship, innovation, and organizational performance.
\end{abstract}

Keywords: intrapreneurship, innovation, competitive advantage, competitiveness, organizational performance

\section{Introduction}

Traditional organizational structures have shown adequate functioning in environments characterized by stability (Volberda, 1996; Porter, 1999). However, since the 1950s, the market and competition changed (Porter; Linde, 1995). The market stability that enabled organizations to enjoy sustainable competitive advantage eventually turned into short periods of advantage, punctuated by frequent interruptions (D'Aveni; Gunther, 1994).

According to Stalk (1988), in the 1960s, organizations demonstrated a trend towards cost optimization as a strategy to achieve a competitive advantage. During the sixties, organizations prioritized increasing product variety, making factories more flexible, reducing the cycle time of the production process, and product distribution (Stalk, 1988). In the 1980s, organizations began to direct their strategies towards human resource practice initiatives (SCHULER and Macmillan, 1984). In the same decade, the adoption of systems began, which link organizations to suppliers, distribution channels, and customers (Johnston \& Vitale, 1988).

The term intrapreneurship emerged in the 1980s to characterize the internal entrepreneurship of organizations (Pinchot, 1985). The intrapreneur presents characteristics and profiles very similar to those of the entrepreneur, but in different contexts. Intrapreneurs differ from traditional workers because traditional workers have a more passive view, and do the things they are told to do, whereas intrapreneurs are, at the same time, thinkers and executors, planners and workers (Pinchot, 1989).

Since the 1990s, competition has been guided by the globalization of markets, the rapid evolution of technology, the reduction of the product life cycle, and the increased aggressiveness of competitors (Volberda, 1996; Santos et al., 
2017). This phenomenon has transformed the structure of organizations, now focused on becoming more competitive because the business world demands from organizations a high capacity to adapt to customer needs. This context is characterized by transitory competitive advantages, despite the need to be sustained for the perpetuation of companies in the market (Kanuri and Mcleod, 2016). The competitive advantage is built through the interaction between internal and environmental factors (Ringov, 2017). Thus, the strategic analysis models and tools are based on external (economic and industrial) and internal analysis of the firm, mainly focusing on human resources (Noble, 2019).

The current business scenario is highly unpredictable. To ensure survival in this environment, companies seek to develop their ability to adapt, creating mechanisms to identify the changes needed to take advantage of opportunities and resistance to market threats. Consequently, organizations increasingly seek to adopt practices that enable intrapreneur behavior in their premises, and according to the conception of (Schumpeter, 1982), this behavior is characterized by the alignment of company members in search of innovative solutions for the development of the organization and the construction of competitive advantage.

In this way, intrapreneurship and innovation go hand in hand and are dynamic and holistic processes in which the behavior of employees combined with favorable organizational factors affect organizational development (Lechner \& Gudmundsson, 2014). Thus, innovation depends on the intrapreneur's ability to be creative, which becomes a critical component in the process of opportunities recognition (Alvarez \& Barney, 2014). Studying the phenomenon that relates intrapreneurship and innovation is a crucial factor in understanding its role in the survival, success, development, and maintenance of competitiveness of organizations (Urban \& Wood, 2015). It fosters discussion on the need to value human capital in companies, as well as the development and adoption of technology.

The current article presents reflections on how intrapreneurship evolved, its characteristics, factors that precede it, and to discuss the role of intrapreneurship and innovation in the development and competitiveness of organizations, by checking the available academic literature. The article is structured in 5 chapters. After this introductory chapter, methodological aspects are addressed. In the sequence, the literature review is dealt with, which is subdivided into the following themes: origin, evolution and characteristics of the term intrapreneurship; factors that precede intrapreneurship; innovation concepts and classifications; competition between firms; and the relationship between intrapreneurship and innovation in generating the competitive advantage of organizations is discussed. Finally, the discussion and concluding remarks are presented.

\section{Methodological Aspects}

The study selected and analyzed scientific articles published in journals and indexed in databases based on intra-entrepreneurship, innovation, competitiveness, and competitive advantage. Therefore, it is a systematic review of the literature (Brizola \& Fantin, 2017), of a descriptive-discursive nature (Gomes \& Oliveira, 2014).

The methodological approach searched the available literature from different research in databases (Ebsco Host, Portal de Periódicos CAPES, and Web of Science) using as keywords the terms: corporate entrepreneurship, intrapreneurship, innovation, competitiveness, and competitive advantage (in Portuguese and English). No form of filter was used to limit periods, areas of publication, and other tools available in the databases. Their accessibility and scope justify the use of these databases. The use of more than one database allowed a more comprehensive coverage of the survey. The keywords used in the research are justified because they represent the goal of the research and the related themes.

Table 1 shows the search results in the three databases for each keyword. The period was obtained in the database.

Table 1. Search results according to keyword and database

\begin{tabular}{llll}
\hline Database & Keyword & Results & Period \\
\hline CAPES & Intraempreendedorismo & 58 & $2008-2018$ \\
\hline CAPES & Intrapreneurship & 2,495 & $1985-2018$ \\
\hline CAPES & Inovação & 17,906 & $1800-2018$ \\
\hline CAPES & Innovation & $1,724,489$ & $1600-2018$ \\
\hline CAPES & Competitividade & 9,956 & $1987-2018$ \\
\hline CAPES & Competitiveness & 523,682 & $1999-2018$ \\
\hline
\end{tabular}




\begin{tabular}{llll}
\hline CAPES & Vantagem Competitiva & 3,454 & $1992-2018$ \\
\hline CAPES & Competitive Advantage & 2,689 & $1992-2018$ \\
\hline Web of Science & Intraempreendedorismo & 0 & $1945-2018$ \\
\hline Web of Science & intrapreneurship & 286 & $1945-2018$ \\
\hline Web of Science & Inovação & 36 & $1945-2018$ \\
\hline Web of Science & Innovation & 188,319 & $1945-2018$ \\
\hline Web of Science & Competitividade & 6 & $1945-2018$ \\
\hline Web of Science & Competitiveness & 43,431 & $1945-2018$ \\
\hline Web of Science & Vantagem Competitiva & 1 & $1945-2018$ \\
\hline Web of Science & Competitive Advantage & 27,670 & $1945-2018$ \\
\hline EBSCO HOST & Intraempreendedorismo & 0 & $1986-2018$ \\
\hline EBSCO HOST & intrapreneurship & 163 & $1986-2018$ \\
\hline EBSCO HOST & Inovação & 446 & $1986-2018$ \\
\hline EBSCO HOST & Innovation & 149,369 & $1986-2018$ \\
\hline EBSCO HOST & Competitividade & 62 & $1986-2018$ \\
\hline EBSCO HOST & Competitiveness & 23,368 & $1986-2018$ \\
\hline EBSCO HOST & Vantagem Competitiva & 31 & $1986-2018$ \\
\hline EBSCO HOST & Competitive Advantage & 19,245 & $1986-2018$ \\
\hline
\end{tabular}

Source: Survey data

Initially, the selection of the bibliographic material considered three criteria: most cited authors (e.g., Antonic, Hisrich, Peters, Shepherd, Dornelas, and Zahra), classical authors (e.g., Pinchot, Schumpeter, and McClelland), and current researches (published in the last 5 years). In this phase, we have selected 100 works. Later, we evaluated and analyze their content, to know the research goals of each article. After that, we selected 81 works as references for our research. This approach allowed us to debate the existing relations between intra-entrepreneurship and innovation, together with its possible impacts on the development and competitiveness of organizations.

\section{Literature Review}

In the following sections, some aspects related to intrapreneurship are presented. This topic aims to provide the reader with more knowledge of intrapreneurship evolution, characteristics, and the factors that precede it, as well as its relationship with innovation and competitiveness.

\subsection{Evolution and Characteristics of Entrepreneurship}

The term entrepreneurship was coined in the eighteenth century by Cantillon, focusing on the economic function of the entrepreneur. Since then, researchers contributed to the theme and concept of entrepreneurship. The contributions of the entrepreneur to (McClelland, 1972) strengthened the recognition of the entrepreneurship role for society and its consequences for economic development. (Shumpeter, 1982) Defended entrepreneurship as a source of innovation, driving productivity, and competitiveness of organizations.

The term intrapreneurship emerged in the 1980s, with the advances in entrepreneurship literature and the entrepreneurial profile, when researchers incorporated the new concept created by Pinchot (1985) to highlight internal entrepreneurship in organizations. Entrepreneurial practices within organizations can have good adhesion, development, and innovations when someone assumes and performs the function of an intrapreneur (Pinchot, 1989; Pinchot \& Pellman, 1999).

(Schumpeter, 1982) states that the ability to identify and explore opportunities are striking characteristics of the entrepreneur, in addition to the ability to take calculated risks and make the best use of available resources. In this sense, intra-entrepreneurship, internal corporate entrepreneurship (Jones \& Butler, 1992) or corporate entrepreneurship (Stopford \& Baden-Fuller, 1994) refer to the concept of entrepreneurship as the process of 
discovering and developing an opportunity, of creating value through innovation and taking advantage of this opportunity at the expense of human resources and capital in a new or existing company (Churchill, 1992).

In this way, the intrapreneur presents characteristics and profile very similar to the entrepreneur, but in different contexts. Intrapreneurs are active within organizations, adopting within this environment the practice and culture of creativity, proactivity, and innovation. The intrapreneur instigates innovation within organizations, establishing a favorable environment for the creative and innovative process (Hisrich \& Peter, 2004).

Intrapreneurs differ from traditional workers. The later accept the notion that their visions have no value, and all that is required or desired of them is to do the things they are told to do. However, intrapreneurs are, at the same time, thinkers and doers, planners and workers. They have this need because they would hardly find anyone to carry out their plans in their place, and they would possibly not allow it (Pinchot, 1989).

In this sense, the intrapreneur plays an essential role as an agent of change in organizations. (Filion, 2004) conceptualizes intrapreneur as the individual who holds the competence to lead and advise the organization where he works on the alternatives, paths, and what should be done for development and innovation. Intrapreneurship is characterized by actions of change and optimization of organizations with a focus on customers and stakeholders (Hashimoto, 2006). (Dornelas, 2009) considered the behavior of people and groups, in the direction of renewal and innovation within organizations as one of the characteristics of intrapreneurship.

(Daokui Li, Feng, \& Jiang, 2014) highlighted that, in a dynamic and competitive environment, the leading organizations that want to maintain themselves in the market should always seek and support the intrapreneurs. They consistute a potential agenda for change in the search for a better revitalization and high performance of the company, through innovation in products and processes (Thus, Zahra, Randerson, \& Fayolle, 2013). Emphasized that intrapreneurs seek in corporate environments to discover new paths and solutions for the improvement or innovation of products, projects, and organizational processes.

The competencies are related to the desire for self-realization of the intrapreneur, passing through its potential to plan and transform ideas into results and opportunities, transform its freedom, incentive, and resources of the environment where it works into innovations, dedicating it hard to convert ideas into products (Pinchot, 1989). Thus, becoming an agent of change in the work environment depends on the space created for the exercise of ideas and creativity, as well as the constant search for growth and professional achievement and career, which together can culminate in excellent results for organizations and society (Pinchot, 1989).

In the acceleration of innovation within companies, no matter the hierarchical level, the intrapreneur is the strategic agent of change. The basis of the entrepreneur is directly linked to his innovative capacity, willingness to experience emotions, risks, the relative degree of dependence in decisions, and development of ideas (Filion, 2004). Vision already addressed by (Pinchot, 1989), when highlighting the intrapreneur as a driver of growth and expansion of an organization, through innovation, presenting a differentiated and advantageous behavior for corporations in the competitive context.

(Russell, 1999) adds that internal innovations require direct actions from motivated employees and are influenced by organizational practices and characteristics of the business environment. Therefore, intrapreneurs individuals cannot be seen as threats to the system and organizational structures. The vision of an intrapreneur is not only quantitative or theoretical but also demonstrates a feeling for the business. He is an active participant in the organizational system and not an enemy. He may not even eventually comply with pre-established rules, but most of the time, he follows them and is aware of their importance.

Among the most predominant characteristics in researches that deal with the theme are the innovative, proactive and creative behavior, the ability to seek and explore opportunities, initiative, independence and self-confidence, desire for growth and personal and professional self-realization (Pinchot, 1989; Dornelas, 2003; Hisrich \& Peters, 2004; Emmendoerfer, Valadares, \& Balbi, 2008).

The development of intra-entrepreneurial characteristics and competencies depends on a motivating environment of organizations concerned and dedicated to the growth and development of their products and processes to meet the expectations of customers and the market. Thus, the individual can only perform personally and professionally in the environment of organizations, from the moment he is encouraged to develop their entrepreneurial skills, becoming an entrepreneur inserted in the organizational environment (Hisrich \& Peters, 2004). 


\subsection{Preceding Factors of Intrapreneurship}

Intrapreneurship is based on the exercise of creativity for innovation within companies, based on the actions of entrepreneurs within organizations that are committed as if they own the company (Dornelas, 2003). Other structural dimensions favorable to intra-entrepreneurship are rooted in marketing, technological base, available resources, investments, and team (Pinchot, 1989).

According to (Pinchot, 1989), the marketing area consists of an encouraging environment for the intrapreneur by enabling a rapid progression of projects and the dissemination of new products. Thus, the critical aspects that provide an environment of intrapreneurship are sedimented in investments in research and development, in a robust technological base, channeling of resources to relevant areas, stimulation of the personnel structure for innovation.

Concerning the organizational dimension, (Hashimoto, 2006) highlighted the need to discuss intrapreneur autonomy so that decisions can be made and supported by top management. The team of managers must provide an environment of favorable conditions for innovation; one of them is the freedom of creation to achieve the organizational objectives (Emmendoerfer, Valadares, \& Balbi, 2008).

In this context, the development and support of intrapreneurs become a new potential for organizations to develop, perpetuate, maintain, or increase their insertion and participation in the market. Capturing and developing intrapreneurs becomes an escape valve for companies to face the competitiveness of the market, amidst the uncertainties and challenges posed by the dynamics of the environment in which they are inserted. For the promising development of business, especially in environments of uncertainty, the organizations that propose to generate and develop intrapreneurs or corporate entrepreneurs stand out from those that do not give importance to it (Valadares \& Emmendoerfer, 2009).

The development of intrapreneurs provides benefits to the organization and stimulates the individual to go in search of organizational objectives to achieve their own individual goals. Thus, these employees gain a sense of responsibility, the burden, and bonus for the innovation of their work process and products (Stoner \& Freeman, 1999).

Intrapreneurship is stimulated by the internal environment of the organization, shaped by the behavior of management, management style, and guidance; transparency in communication, exchange of ideas and knowledge; favorable environment and open to change, learning and implementation of new ideas; flexible, informal organizational structure with few hierarchical levels; long-term strategy; organizational systems and practices that encourage creativity and innovation (Goosen et al., 2002).

The management and orientation mode are the variables belonging to the organizational environment that allows modeling of intrapreneur behavior. Management style influences intrapreneurship by creating conditions for employees to promote their ideas, implement improvements, recognize and reward their actions, and provide adequate resources and operating procedures (Antoncic \& Hisrich, 2001).

The organizational environment favorable to the development of intra-entrepreneurship necessarily involves the effectiveness and transparency of communication, the fluidity of information, and knowledge sharing. However, the quality and quantity of information and communication will influence the innovative and intra-entrepreneurial actions (Zahra, 1991).

Thus, the informal organizational structure and more loose limits are characteristics that contribute to the best and easiest access to information facilitating intrapreneurship (Baum \& Wally, 2003). (Daft, 2009) highlighted the organic organizational structure with a reduced number of hierarchical levels that encourages teamwork and closer interaction, provides greater flexibility, adaptability, and more clear articulation within organizations. The author also adds that the environment conducive to change represents a corporate culture that stimulates the sharing of knowledge, learning, and the development of innovation.

Another characteristic of the organizational environment favorable to intrapreneurship and innovation is the valuation of long-term strategies, the incentive to systematic planning and the strategy of resource management, adaptation, and long-term focus are crucial strategic factors (Goosen et al., 2002), which increase the capacity of the organization to compete and gain competitiveness (Zahra, 1993).

In this context, the role of leaders as facilitators of innovation of an organization's employees should be highlighted (Rosing, Frese, \& Bausch, 2011). Direct managers and leaders play an important role in critical support and support in overcoming internal limits, as well as providing a balance between the rigidity of procedures and the availability of sufficient time and resources for experiments at a team level (Chiaburu, Lorinkova, \& Van Dyne, 2013). 
(Shalley \& Gilson, 2004) noted the importance of the leader striving to ensure the structure of entrepreneurial work environment that provides creative results, to value the importance of the contribution of each intrapreneur (Hülsheger, Anderson, \& Salgado, 2009) supporting the best and most innovative ideas (Rosing et al., 2011).

Team leaders need to act as facilitators, from the bottom up, in intrapreneurship initiatives, when the organization tends to encounter difficulties in actively managing intrapreneurship (Palanski \& Vogelgesang, 2011). According to (Leroy, Palanski, \& Simons, 2011), team leaders enable innovation by increasing the level of autonomy and decision-making they have about their teams, stimulating the individual initiatives of their leaders.

Corporate climates that support entrepreneurship must provide appropriate reward systems, top management support, explicit goals, and appropriate organizational values, which signal to employees that the action of entrepreneurial behavior is desirable (Hornsby et al., 2009).

\subsection{Innovation: Concepts and Classifications}

The term innovation appeared during the industrial revolution in the 20th century. At that time, (Schumpeter, 1934) argued that the growth of the economy would be related to the reorganization of its activities, whether through the implementation of new routines, the readjustment of existing processes, or the launch of new products and services. The author proposed the concept of "creative destruction", where to build something new requires deconstructing what already exists.

Some authors were concerned with classifying the types of innovation. (Hisrich, Peters, \& Shepherd, 2012) consider three types of innovation, namely: revolutionary innovation, technological innovation, and common innovation. Table 2 shows the concept pointed out by the authors for these three types of innovation and their peculiarities.

Table 2. Types of innovation according to (Hisrich, Peters, \& Shepherd, 2012)

\begin{tabular}{ll}
\hline Type of innovation & Characteristics \\
\hline & $\checkmark$ It is the rarest kind of innovation; \\
& $\checkmark$ They generally have unique characteristics; \\
Revolutionary innovation & $\checkmark$ Future innovations are developed from this; \\
& $\checkmark$ It should be protected to the maximum by patent registration; \\
& $\checkmark$ Examples: Steam engine, airplane, wristwatch, computer, airplane, \\
& automobile, nanotechnology, etc. \\
\hline \multirow{3}{*}{ Technological innovation } & $\checkmark$ It occurs more frequently than technological innovation; \\
& $\checkmark$ It is not at the same level as discovery and scientific advances; \\
& $\checkmark$ They also need protection (patents); \\
& $\checkmark$ Examples: laptops, tablets, iPhones, smartwatches, jet aircraft, and others. \\
\hline & $\checkmark$ It occurs more frequently; \\
& $\checkmark$ They usually extend a technological innovation in order to generate a \\
& different and more effective commercial appeal; \\
& $\checkmark$ They are usually born from an analysis and market demand (Market-pull); \\
& $\checkmark$ The pressure for technology supply does not affect its creation \\
& (technology-push); \\
& $\checkmark$ Examples: Change in the format of product packaging, change in the layout \\
of products on shelves, new distribution means, etc.
\end{tabular}

Source: Adapted from (Hisrich, Peters, \& Shepherd, 2012)

The (Oslo, 2018) defines four types of innovations related to the activities of companies, namely: product innovations, process innovations, organizational innovations, and marketing innovations. 
According to the Manual, product innovations involve significant changes in the potential of products and services. They include entirely new products and services and important enhancements to existing products. Process innovations, on the other hand, represent significant changes in production and distribution methods.

Organizational innovations refer to the implementation of new organizational methods, such as changes in business practices, in the workplace organization, or the company's external relations. Marketing innovations, on the other hand, involve the implementation of new marketing methods, including changes in product design and packaging, product promotion and placement, and pricing methods for goods and services.

In this sense, the theme innovation is commonly cited in the academic and business environment to characterize a novelty or a modification in something that already exists (Quinello \& Nicoletti, 2009). (Hashimoto, 2006) pointed out that to be considered an innovation, the change can be of large or small proportion as long as it is positive and causes improvements or a paradigm shift.

The spirit of innovation is considered by (Hisrich, Peters, \& Shepherd, 2012) as a key element of intrapreneurship. The authors also indicate that the increase in competitiveness among companies spread the need for intrapreneurship development, together with the need for innovation to survive in a competitive market.

The next chapter discusses this relationship between intrapreneurship, innovation, and competitiveness.

\subsection{Competition Between Organizations}

After 1871, the concept of competition (Stingler, 1957) and the way firms compete (Pereira, 2015) became a recurrent target of studies in the economic sciences. Until then, the global market was characterized by stability and lack of competition (Porter \& Linde, 1995). At that time, competition was hardly noticed in most sectors and regions. Even when there were competitors, the rivalry was mild. This allowed for the prevalence and domination by a few firms, which relied on the formation of cartels and government. (Porter, 1999).

The market and competition have changed, especially since the 1960s and 1970s (Porter \& Linde, 1995). These changes consisted in the replacement of stability where firms remained for long periods in a competitive position by competition characterised by short periods of advantage, punctuated by frequent interruptions (D'aveni \& Gunther, 1994). Since the nineties, the rules of competition have been drastically changed, mainly by the influence of the globalization of markets, the rapid evolution of technology, the shortening of the product life cycle and the increased aggressiveness of competitors (Volberda, 1996).

In this environment, with the advancement of information technology, especially with regard to communication and data transfer, companies, which previously competed with a small group of local companies, began to compete with companies located in the most diverse regions of the world (Santos et al., 2017). This phenomenon has transformed the structure of organizations, now focused on becoming more competitive, because the business world, today, demands from organizations a great capacity for dynamism (Santos et al., 2017). Competition increases the productivity and profitability of firms, especially those in the private sector. As Adam Smith observed, the greater the number of competitors in the market, the greater the effort of firms to obtain gains and thus outperform their competitors (Sledge, 2011). In this way, firms began to be pressured to innovate in order to survive, develop and remain competitive (Urban \& Wood, 2015) in this new social, cultural, human and economic context (Schwab, 2017).

As they have already stated (Hâkansson \& Snehota, 1989), "No business is an island". With this statement, the authors suggest that regardless of their location, most businesses are affected by global competition. For this reason, even domestic firms should consider businesses located in the most different regions of the world as rivals. Second (Sledge, 2011), the expansion of the Internet has allowed small businesses, with virtually no physical structure, to compete and gain market share in the world economy. For the author, the accessibility to international travel and the increase in disposable income, created possibilities for the increase in worldwide demand for products and services that were previously local only.

The comparative advantage in resources allows the firm to achieve superior performance through a position of competitive advantage in some segment or market segments (Hunt \& Morgan, 1995). In this environment, competitors try to neutralize and, or, outperform the advantageous firm through acquisition, imitation, substitution or major innovation (Hunt \& Morgan, 1995). The new paradigm of competition is based on dynamics and innovation, surpassing the firms with greater innovative capacity (Porter \& Linde, 1995). Around the world, organizations are continually trying to develop new and innovative ways to increase their competitiveness (Rao \& Holt, 2005). Therefore, global competition is a topic that calls the attention of several segments, such as employees, corporate 
directors, government managers and scholars (Sledge, 2011). For (Porter, 1999), it advises that companies and regions should develop their ability to compete.

For (Teece, Pisano, \& Shuen, 1997) the ability to innovate refers to the firm's ability to integrate, build and reconfigure internal competencies in order to react or bring about changes in the business environment. Firms should consider innovation in terms of business models and not just in terms of new products or new industrial processes (Tell et al., 2016). Innovation, especially in the face of great competitive pressure, is considered a strategic factor for the survival and growth of firms (Pascucci, 2018). The ability of a firm to innovate determines the speed and degree of alignment of the firm's resources, including its business model(s) to meet customer needs and aspirations. To do so, firms must be able to periodically transform aspects of their structure and culture, as well as detect and seize opportunities. In this way, firms are able to proactively reposition themselves to deal with threats and opportunities as they arise (Teece, 2018).

The capacity for innovation can be taken as a particularity of each firm (Teece, Pisano, \& Shuen, 1997), or considered as a characteristic of an industry, as systemic properties, resulting from shared routines and practices that develop in a particular way (Eisenhardt \& Martin, 2000). The industry operates with a constant cycle of innovation and imitation, where companies seek innovative capabilities to gain advantage. In this cycle, as they succeed, other companies in the industry follow suit, taking loans, adapting and improving what their competitors are doing (Lampel \& Shamsie, 2003).

Both the scope and maintenance of a position depends on the market and industry pressure. A company loses its competitive position in the competitive market when it fails to respond to external changes (Lado, Boyd, \& Wright, 1992). A sustainable and strong competitive position can be achieved by offering unique products and services, with lower costs and good characteristics, compared to its main competitors (Side, Boyd, \& Wright, 1992). Competitive advantages, sustained over time, whether in cost or differentiation (Newbert, 2008), lead to increased performance, profitability and, or, market share (Kamukama et al., 2017).

According to (Hâkansson \& Snehota, 1989) firms are considered effective and competitive when they manage to accumulate resources throughout their existence, through interaction with the environment in which they are inserted. For the authors, this accumulation is fundamental to their existence. In this sense, the concept of competitive advantage can be defined as a compound of value creation superior to competitors (Ghemawat \& Rivkim, 2006), in terms of growth and profitability (Brito \& Brito, 2014). A strong competitive position, besides being considered a key success factor for companies, can indicate market power (Maertens, 2018). In addition to tangible resources, firms are composed of idiosyncratic and difficult to negotiate assets and skills, such as know-how. According to (Teece, 2007), sustainable advantage requires unique dynamic resources. In this sense, knowledge and information are considered fundamental sources of wealth (Stewart, 1998), as intangible resources that influence the creation of value in firms (Perez \& Famá, 2006).

\subsection{Intrapreneurship, Innovation, and Competitiveness}

Innovation plays a vital role in the development of organizations and the economy by stimulating the disruption of the balance of a stable scenario through entrepreneurial individuals who can articulate and combine resources to offer goods and services that meet the needs of consumers and the market (Schumpeter, 1934). Innovation also contributes to the development of a country since it brings important contributions to its economic growth (Cameron, 1996).

The ability to innovate is considered a determining factor for the competitiveness of organizations. Thus, it is necessary to discuss, observe, and analyze the role of innovation through intrapreneurship in business development and success (Schumpeter, 1934).

With an essential role in the conception and maintenance of competitive advantage in organizations, innovation is a relevant strategy to reinvigorate them (Bessant et al., 2005). The closed innovation, the base of large companies, which considered as a competitive advantage to have the most intelligent people and the best resources, assuming that a discovery or development will give the company the advantage of first commercializing the innovation, and thus, winning the market (Chesbrough, 2003). For open innovation, an emerging area that has developed with the evolution of the media, globalization, the need to disseminate knowledge, and a higher number of investment options (Di Petta, 2018) All those are fundamental for maintaining competitive advantage and necessarily pass through entrepreneurship and intrapreneurship.

Open innovation extends to the intra-organizational, extra-organizational, inter-organizational, sector, regional innovation systems, and society levels. The relationship between open innovation and entrepreneurship also occurs at 
all these levels and can contribute to the entrepreneur identifying opportunities in different contexts and types of organizations (Abella et al., 2018). (Abella et al., 2018) highlight that open innovation has relevant implications for entrepreneurship in new ventures, as well as for intrapreneurship. As the authors emphasize, few studies emphasized the relationship between entrepreneurship and open innovation.

Intrapreneurship underwent an evolution in the last 40 years to qualify as a strategy that could contribute and stimulate innovation and deal with the competitive realities of globalized world markets (Kuratko et al., 2015). Intrapreneurship and innovation started to move together and are not limited to new ventures, but constitute dynamic and holistic processes in which the behavior of employees allied to favorable organizational factors affect the development of organizations (Lechner \& Gudmundsson, 2014).

In this way, organizations that in the past did not value and recognize intrapreneurship as something useful for their development began to foster entrepreneurship and innovation to survive, achieve success, and remain competitive in increasingly dynamic markets (Urban \& Wood, 2015).

Innovation is closely linked to the intrapreneur's ability to be creative and to present what author (Urban, 2017) calls an "entrepreneur alert", which was recognized as a critical component of the process of identifying opportunities, where individuals neurologically identify opportunities of more lasting value (Alvarez \& Barney, 2014).

According to (Valliere, 2013), the identification of entrepreneurial opportunities is based on the entrepreneur's cognitive structure, which allows him to identify quick responses to challenges in the environment. Thus, the spirit of intrapreneurship that permeates the organization is essential to ensure a continuous flow of innovation.

\section{Discussion}

With the literature review, it was possible to verify that the term intra-entrepreneurship is not new, originating in the 1980s, when the strategies of the firms presented a direction for the practices focused on human resources, as a way to achieve competitive advantage. The innovative capacity is part of the essence of the intra-entrepreneur (Orchard, 2015), together with characteristics such as self-confidence, perseverance, willingness to take risks, and others. This behavior can be stimulated, mainly by an environment conducive to the development of intra-entrepreneurship, which is characterized by the promotion of innovation (Orchard; Ribiere \& Achtzehn, 2018). This environment is what encourages intra-entrepreneurship and defines the investments to be made in innovation in organizations. Leadership is a relevant factor in this context (Orchard; Ribiere \& Achtzehn, 2018).

Organizations exist in a context of hypercompetition and therefore need to continually innovate in order to maintain or improve their competitive advantage over their competitors. Intra-entrepreneur plays a crucial role in this search. $\mathrm{He}$ is the one who directs the organization, identifying opportunities for improvement, both internal and external, as well as threats. The identification of the need to adopt new technologies is part of this search for organizational development. Thus, intra-entrepreneurship, technology, and innovation are components that can together provide better results and consequently, competitive advantage to organizations. As pointed out in the previous chapters, the literature makes these conclusions possible.

In this sense, the academy deals with studies that enable the evolution of knowledge on intra-entrepreneurship issues, innovation, and competitive advantage in organizations. A vast list of studies on the themes can be found, as shown in Table 1. In the practice of organization management, managers seem to encourage employee autonomy and creativity. The job market itself requires that job applicants have characteristics of the intra-entrepreneur profile. The competition scenario is conducive to the adoption of these premises as an integral part of the organizations' strategies. Thus, organizational structures and leadership styles tend to adapt to this reality.

Because technology, production processes, and products are often easily imitated, organizations tend to sustain their competitive advantage through their intangible assets. In this sense, intra-entrepreneurship becomes a relevant tool in organizations' strategy. The consumer profile is currently demanding and increasingly values good service and convenience. The human factor in organizations, combined with technology and innovation, present themselves as solutions for effective and efficient service to consumer demands. The organizations that previously distinguished the best leaders from others for their intelligence, commitment, energy, the courage of conviction, integrity, began to expect these qualities from almost all that make up their structure. Thus, the time when some rational managers were able to manage everything with rational numbers, it seems, was just an anomaly, or part of a somewhat archaic era (Huey \& Sookdeo, 1994), very different from the current era that is characterized by the fast pace and constant change. 


\section{Concluding Remarks}

The current article contributed to the knowledge of the intra-entrepreneurship theme through a literature review, addressing the development of the concept, characteristics, and preceding factors. Here, we also discuss the relationship between intrapreneurship and innovation and their impact on the development of organizations.

The term intrapreneurship was coined in the 1980s by (Pinchot, 1985) to characterize the entrepreneurs inserted within the organizations. Intrapreneurs differ from entrepreneurs and also from other employees who work in organizations. Intrapreneurs differs from entrepreneurs in terms of contexts of operation, and the entrepreneur has a more wide radius of action. As for the traditional employees, the intrapreneur differs in the way of acting and thinking. Among other characteristics of the intrapreneur, we highlight the innovative, proactive and creative behavior, the ability to seek and explore opportunities, initiative, independence and self-confidence, desire for growth and personal and professional self-realization, and willingness to assume risks responsibly.

Intrapreneurship is stimulated by the organization's internal environment, shaped by management behavior, management style and orientation. It is also influenced by transparency in communication, exchange of ideas and knowledge; a favorable environment open to change, learning and implementation of new ideas; flexible, informal organizational structure with few hierarchical levels; long-term strategy; organizational systems and practices that encourage creativity and innovation; appropriate reward, explicit goals, support from senior management and appropriate organizational values. All that function as a signal to employees that the action of entrepreneurial behavior is desirable.

According to (Lechner \& Gudmundsson, 2014), intrapreneurship and innovation go hand in hand and constitute dynamic and holistic processes in which the behavior of employees, combined with favorable organizational factors, affect the development of organizations and the possibility of developing competitive advantage, not limited to new undertakings. Companies adopt intrapreneurship and innovation in an attempt to survive, succeed, and remain competitive in the markets (Urban \& Wood, 2015). In this way, it is perceived as a relationship between intrapreneurship and innovation as factors that can provide positive impacts on the performance of organizations and, consequently, on their competitiveness.

This article contributes to the literature on intrapreneurship, demonstrating its importance, together with innovation for organizational development. The practical contribution of the article is in the approach of the themes in order to stimulate the managers to be interested in the agenda, which is important for the management in the current global context, given the effects of globalization on the competition. The study presents the limitation of the little deepening of the theme. For future research, we suggest seeking empirical, quantitative and qualitative research, which confirm the relationship between intrapreneurship, innovation and organizational performance.

\section{References}

Abella, A., Ortiz, U. C. M., \& Pablos, H. C. (2015). Information reuse in smart cities' ecosystems. El Profesional de La Información, 24(6), 838-844. https://doi.org/10.3145/epi.2015.nov.16

Alvarez, S. A., \& Barney, J. B. (2014). Entrepreneurial opportunities and poverty alleviation. Entrepreneurship Theory and Practice, 38(1), 159-184. https://doi.org/10.1111/etap.12078

Antoncic, B., \& Hisrich, R. D. (2001). Intrapreneurship: Construct refinement and cross-cultural validation. Journal of Business Venturing, 16(5), 495-527. https://doi.org/10.1016/S0883-9026(99)00054-3

Brito, R. P. D., \& Brito, L. A. L. (2014). Dynamics of competition and survival. BAR-Brazilian Administration Review, 11(1), 64-85. https://doi.org/10.1590/S1807-76922014000100005

Brizola, J., \& Fantin, N. (2017). Revisão da Literatura e Revisão sistemática da Literatura. Revista de Educação do Vale do Arinos-RELVA, 3(2), 23-39. Retrieved from https://periodicos.unemat.br/index.php/relva/article/view/1738/1630

Caiazza, R., Volpe, T., Stanton, J. L., Griffith, C. J., Tell, J., Hoveskog, M., ... Stahl, J. (2016). Business model innovation in the agri-food sector: A literature review. British Food Journal. https://doi.org/10.1108/BFJ-08-2015-0293

Chesbrough, H. (2003). Open innovation, the new imperative for creating and profiting from technology. Boston, MA: Harvard Business School Press. 
Chiaburu, D. S., Lorinkova, N. M., \& Van Dyne, L. (2013). Employees' social context and change-oriented citizenship: A meta-analysis of leader, coworker, and organizational influences. Group \& Organization Management, 38(3), 291-333. https://doi.org/10.1177/1059601113476736

Churchill, N. C. (1992). Research issues in entrepreneurship. In D. L. Sexton, \& J. D. Kasarda (Eds.), The state of the art of entrepreneurship (pp. 579-596). Boston, MA: Pws-Kent.

D'Aveni, R. A. (1994). Hypercompetition: managing the dynamics of strategic maneuvering. New York: WirtschaftsWoche.

D'aveni, R. A., \& Gunther, R. (1994). Hypercompetition. Managing the dynamics of strategic maneuvering. In B. Cornelius, \& E. Rainer (Eds.), Das summa summarum des management (pp. 83-93). New York: Free Press. https://doi.org/10.1007/ 978-3-8349-9320-5_8

Daft, R. L. (2009). Principles of management. New Delhi: Cengage learning.

Di Petta, A., Ferraz, R. R. N., Pedron, C. D., \& Quoniam, L. (2018). Mineração de patentes e pequenas empresas: uma revisão sistemática da literatura sobre oportunidades de negócio sob a ótica da inovação aberta. Revista de Empreendedorismo e Gestão de Pequenas Empresas, 7(2), 170-200. https://doi.org/10.14211/regepe.v7i2.670

Dornelas, J. C. A. (2009). Empreendedorismo corporativo. Rio de Janeiro: Elsevier.

Eisenberger, R., \& Cameron, J. (1996). Detrimental effects of reward: Reality or myth?. American Psychologist, 51(11), 1153. https://doi.org/10.1037/0003-066X.51.11.1153

Eisenhardt, K. M., \& Martin, J. A. (2000). Dynamic capabilities: what are they?. Strategic Management Journal, 2l(10-11),

1105-1121. https://doi.org/10.1002/1097-0266(200010/11)21:10/11<1105::AID-SMJ133>3.0.CO;2-E

Emmendoerfer, M. L., Valadares, J. L., \& Balbi, R. V. (2008). Esforços para a construção do conhecimento sobre empreendedorismo interno: reflexões e perspectivas a partir de eventos da ANPAD (1997-2007). Simpósio de Gestão da Inovação Tecnológica, 25.

Filion, L. J., \& Laferté, S. (2004). Um roteiro para desenvolver o empreendedorismo. III Encontro Internacional de Empreendedorismo. Recife: IEL Instituto Euvaldo Lodi.

Ghemawat, P., \& Rivkin, J. W. (1998). Creating competitive advantage. Boston: Harvard Business.

Gomes, I. S., \& Oliveira, C. I. (2014). Guia para estudos de revisão sistemática: uma opção metodológica para as Ciências do Movimento Humano. Movimento (ESEFID/UFRGS), 20(1), 395-411. https://doi.org/10.22456/1982-8918.41542

Goosen, C. J. (2002). Key factor intrapreneurship: The development of a systems model to facilitate the perpetuation of entrepreneurship in the larger South African Organisation. Doctoral dissertation, Stellenbosch: Stellenbosch University.

Håkansson, H., \& Snehota, I. (2006). No business is an island: The network concept of business strategy. Scandinavian Journal of Management, 22(3), 256-270. https://doi.org/10.1016/j.scaman.2006.10.005

Hashimoto, M. (2006). Espírito empreendedor nas organizações: aumentando a competitividade através do intra-empreendedorismo. São Paulo: Saraiva.

Hisrich, R. D., \& Peter, M. P. (2004). Empreendedorismo. Porto Alegre: Bookman.

Hisrich, R. D., Peters, M. P., \& Sheperd, D. A. (2012). Entrepreneurship. New York: McGraw-Hill/Irwin.

Hornsby, J. S., Kuratko, D. F., Shepherd, D. A., \& Bott, J. P. (2009). Managers' corporate entrepreneurial actions: Examining perception and position. Journal of Business Venturing, 24(3), 236-247. https://doi.org/10.1016/j.jbusvent.2008.03.002

Huey, J., \& Sookdeo, R. (1994). The new post-heroic leadership Ninetyfive percent of American managers today say the right thing. Five percent actually do it. That's got to change. Fortune Magazine, 21.

Hülsheger, U. R., Anderson, N., \& Salgado, J. F. (2009). Team-level predictors of innovation at work: a comprehensive meta-analysis spanning three decades of research. Journal of Applied Psychology, 94(5), 1128. https://doi.org/10.1037/a0015978

Hunt, S. D., \& Morgan, R. M. (1997). Resource-advantage theory: a snake swallowing its tail or a general theory of competition?. Journal of Marketing, 61(4), 74-82. https://doi.org/10.1177/002224299706100406 
Johnston, H. R., \& Vitale, M. R. (1988). Creating competitive advantage with interorganizational information systems. MIS Quarterly, 153-165. https://doi.org/10.2307/248839

Jones, G. R., \& Butler, J. E. (1992). Managing internal corporate entrepreneurship: An agency theory perspective. Journal of Management, 18(4), 733-749. https://doi.org/10.1177/014920639201800408

Kamukama, N., \& Sulait, T. (2017). Competitive advantage: Mediator of managerial competence and financial performance of commercial banks in Uganda. African Journal of Economic and Management Studies, 8(2), 221-234. https://doi.org/10.1108/AJEMS-10-2016-0142

Kanuri, S., \& McLeod, R. W. (2016). Sustainable competitive advantage and stock performance: the case for wide moat stocks. Applied Economics, 48(52), 5117-5127. https://doi.org/10.1080/00036846.2016.1170938

Kuratko, D. F., Hornsby, J. S., \& Hayton, J. (2015). Corporate entrepreneurship: the innovative challenge for a new global economic reality. Small Business Economics, 45(2), 245-253. https://doi.org/10.1007/s11187-015-9630-8

Lado, A. A., Boyd, N. G., \& Wright, P. (1992). A competency-based model of sustainable competitive advantage: Toward a conceptual integration. Journal of Management, 18(1), 77-91. https://doi.org/10.1177/014920639201800106

Lampel, J., \& Shamsie, J. (2003). Capabilities in motion: New organizational forms and the reshaping of the Hollywood movie industry. Journal of Management Studies, 40(8), 2189-2210. https://doi.org/10.1046/j.1467-6486.2003.00417.x

Lechner, C., \& Gudmundsson, S. V. (2014). Entrepreneurial orientation, firm strategy and small firm performance. International Small Business Journal, 32(1), 36-60. https://doi.org/10.1177/0266242612455034

Leroy, H., Palanski, M. E., \& Simons, T. (2012). Authentic leadership and behavioral integrity as drivers of follower commitment and performance. Journal of Business Ethics, 107(3), 255-264. https://doi.org/10.1007/s10551-011-1036-1

Li, D. D., Feng, J., \& Jiang, H. (2006). Institutional entrepreneurs. American Economic Review, 96(2), 358-362. https://doi.org/10.1257/000282806777211775

Maertens, S. (2018). A metric to assess the competitive position of airlines and airline groups in the intra-European air transport market. Research in Transportation Economics, 72, 65-73. https://doi.org/10.1016/j.retrec.2018.07.018

Mcclelland, D. C. (1972). A sociedade competitiva realização e progresso social. Rio de Janeiro: Expressão e Cultura.

Newbert, S. L. (2008). Value, rareness, competitive advantage, and performance: a conceptual-level empirical investigation of the resource-based view of the firm. Strategic Management Journal, 29(7), 745-768. https://doi.org/10.1002/smj.686

OECD/Eurostat. (2019). Oslo manual 2018: guidelines for collecting, reporting and using data on innovation (4th ed.). The Measurement of Scientific, Technological and Innovation Activities, OECD Publishing, Paris/Eurostat, Luxembourg.

Orchard, S. (2015). Entrepreneurship and the human capital of organizational innovation: The intrapreneur. In The entrepreneurial rise in Southeast Asia (pp. 111-138). Palgrave Macmillan, New York. https://doi.org/10.1057/9781137373809_6

Orchard, S., Ribiere, V., \& Achtzehn, D. (2018). The influence of the leader and led relationship on the intrapreneurship environment in UK Smes. Academy of Entrepreneurship Journal.

Palanski, M. E., \& Vogelgesang, G. R. (2011). Virtuous creativity: The effects of leader behavioural integrity on follower creative thinking and risk taking. Canadian Journal of Administrative Sciences/Revue Canadienne des Sciences de l'Administration, 28(3), 259-269. https://doi.org/10.1002/cjas.219

Pascucci, F. (2018). The export competitiveness of Italian coffee roasting industry. British Food Journal, 120(7), 1529-1546. https://doi.org/10.1108/BFJ-05-2017-0306

Pereira, M. D. C. (2015). Competição schumpeteriana e consumidores organizados em rede: uma análise do mercado brasileiro de acesso à internet. Doctoral dissertation, Campinas: Universidade Estadual de Campinas. Retrieved from http://repositorio.unicamp.br/jspui/handle/REPOSIP/286531 
Perez, M. M., \& Famá, R. (2006). Ativos intangíveis e o desempenho empresarial. Revista Contabilidade \& Finanças, 17(40), 7-24. https://doi.org/10.1590/S1519-70772006000100002

Pinchot III, G. (1985). Intrapreneuring: Why you don't have to leave the corporation to become an entrepreneur. University of Illinois at Urbana-Champaign's Academy for Entrepreneurial Leadership Historical Research Reference in Entrepreneurship. Retrieved from https://ssrn.com/abstract=1496196

Pinchot, G. (1989). Intrapreneuring: por que você não precisa deixar a empresa para tornar-se um empreendedor. Harbra.

Pinchot, G., \& Pellman, R. (1999). Intrapreneuring in action: A handbook for business innovation. Berrett-Koehler Publishers.

Porter, M. E. (1999). Competição: estratégias competitivas essenciais. Gulf Professional Publishing.

Porter, M. E., \& Advantage, C. (1985). Creating and sustaining superior performance. Competitive Advantage, 167, 167-206.

Porter, M. E., \& Van der Linde, C. (1995). Toward a new conception of the environment-competitiveness relationship. Journal of Economic Perspectives, 9(4), 97-118. https://doi.org/10.1257/jep.9.4.97

Quinello, R., \& Nicoletti, J. R. (2009). Inovação operacional: entenda Como atitudes inovadoras aplicada nos processos industriais podem agregar valor e alavancar a competitividade de sua empresa. Brasport.

Rao, P., \& Holt, D. (2005). Do green supply chains lead to competitiveness and economic performance?. International Journal of Operations \& Production Management. https://doi.org/10.1108/01443570510613956

Ringov, D. (2017). Dynamic capabilities and firm performance. Long Range Planning, 50(5), 653-664. https://doi.org/10.1016/j.lrp.2017.02.005

Robert Baum, J., \& Wally, S. (2003). Strategic decision speed and firm performance. Strategic Management Journal, 24(11), 1107-1129. https://doi.org/10.1002/smj.343

Rosing, K., Frese, M., \& Bausch, A. (2011). Explaining the heterogeneity of the leadership-innovation relationship: Ambidextrous leadership. The Leadership Quarterly, 22(5), 956-974. https://doi.org/10.1016/j.leaqua.2011.07.014

Russell, R. D. (1999). Developing a process model of intrapreneurial systems: A cognitive mapping approach. Entrepreneurship Theory and Practice, 23(3), 65-84. https://doi.org/10.1177/104225879902300305

Santos, V. F., Sabino, L. R., Morais, G. M., \& Gonçalves, C. A. (2017). E-Commerce: A Short History Follow-up on Possible Trends. International Journal of Business Administration, 8(7), 130-138. https://doi.org/10.5430/ijba.v8n7p130

Schuler, R. S., \& MacMillan, I. C. (1984). Gaining competitive advantage through human resource management practices. Human Resource Management, 23(3), 241-255. https://doi.org/10.1002/hrm.3930230304

Schumpeter, J. A. (1934). Change and the Entrepreneur. Essays of Journal Schumpeter, 4(23), 45-91.

Schumpeter, J. A. (1997). Teoria do desenvolvimento econômico: uma investigação sobre lucros, capital, crédito, juro e o ciclo econômico (1934). Tradução de Maria Sílvia Possas. Coleção Os Economistas. São Paulo: Nova Cultural.

Schwab, K. (2017). The fourth industrial revolution. New York: Crown Business.

Shalley, C. E., \& Gilson, L. L. (2004). What leaders need to know: A review of social and contextual factors that can foster or hinder creativity. The Leadership Quarterly, 15(1), 33-53. https://doi.org/10.1016/j.leaqua.2003.12.004

Shank, N. (2019). Human capital is a strategic entry point to owning sustainable competitive advantage. Remah Journal, 34, 319-340.

Sledge, S. (2011). Dynamic competition: a look at firms in the Fortune Global 500. Competitiveness Review: An International Business Journal. https://doi.org/10.1108/10595421111171939

Stalk, G. (1988). Time-the next source of competitive advantage. Harvard Business Review, 66(4), 41-52.

Stewart, T. A. (1998). Capital intelectual: a nova vantagem competitiva das empresas (Vol. 2). Rio de Janeiro: Campus. 
Stigler, G. J. (1957). Perfect competition, historically contemplated. Journal of Political Economy, 65(1), 1-17. https://doi.org/10.1086/257878

Stoner, J. A. F., \& Freeman, R. E. (1999). Administração. Rio de Janeiro: LTC.

Stopford, J. M., \& Baden-Fuller, C. W. (1994). Creating corporate entrepreneurship. Strategic Management Journal, 15(7), 521-536. https://doi.org/10.1002/smj.4250150703

Teece, D. J. (2007). Explicating dynamic capabilities: the nature and microfoundations of (sustainable) enterprise performance. Strategic Management Journal, 28(13), 1319-1350. https://doi.org/10.1002/smj.640

Teece, D. J. (2018). Business models and dynamic capabilities. Long Range Planning, 51(1), 40-49. https://doi.org/10.1016/j.lrp.2017.06.007

Teece, D. J., Pisano, G., \& Shuen, A. (1997). Dynamic capabilities and strategic management. Strategic Management Journal, $18(7), \quad 509-533$. https://doi.org/10.1002/(SICI)1097-0266(199708)18:7<509::AID-SMJ882>3.0.CO;2-Z

Tidd, J., Bessant, J., \& Pavitt, K. (2000). Managing innovation: integrating technological, market and organisational change. Wiley: Chichester. It has no DOI.

Urban, B., \& Kujinga, L. (2017). The institutional environment and social entrepreneurship intentions. International Journal of Entrepreneurial Behavior \& Research. https://doi.org/10.1108/IJEBR-07-2016-0218

Urban, B., \& Wood, E. (2015). The importance of opportunity recognition behaviour and motivators of employees when engaged in corporate entrepreneurship. Journal of Business Economics and Management, 16(5), 980-994. https://doi.org/10.3846/16111699.2013.799087

Valliere, D. (2013). Towards a schematic theory of entrepreneurial alertness. Journal of Business Venturing, 28(3), 430-442. https://doi.org/10.1016/j.jbusvent.2011.08.004

Volberda, H. W. (1996). Toward the flexible form: How to remain vital in hypercompetitive environments. Organization Science, 7(4), 359-374. https://doi.org/10.1287/orsc.7.4.359

Zahra, S. A. (1991). Predictors and financial outcomes of corporate entrepreneurship: An exploratory study. Journal of Business Venturing, 6(4), 259-285. https://doi.org/10.1016/0883-9026(91)90019-A

Zahra, S. A., Randerson, K., \& Fayolle, A. (2013). Part I: The evolution and contributions of corporate entrepreneurship research. Management, 16(4), 362-380. https://doi.org/10.3917/mana.164.0362

\section{Copyrights}

Copyright for this article is retained by the author(s), with first publication rights granted to the journal.

This is an open-access article distributed under the terms and conditions of the Creative Commons Attribution license (http://creativecommons.org/licenses/by/4.0/). 